\title{
KONSEP ADIL DALAM POLIGAMI: Telaah Pemikiran Mushthofa Al-'Adawï dalam Tafsir Al-Tashïl Lita'wïl Al-Tanzïl
}

\author{
Yufni Faisol \\ Universitas Islam Negeri (UIN) Imam Bonjol Padang Sumatra Barat \\ E-mail:yufnifaisol.ipb@gmail.com
}

\begin{abstract}
Poligamy has been a sensitive issue and a heated debate among ulamas, Muslim scholars, and interpreters of the Qur'an since a long time ago. Among various opinions of the Qur'an interpreters on interpreting verses considered as the source of law on poligamy and which is written in the books of the Qur'anic exegeses, it can be classified into three groups. Firstly, it is the group of interpreters who allow poligamy absolutely and extremely flexible. Secondly, it is the group of interpreters who allow poligamy but under very strict requirements. Finally, it is the group of interpreters who reject and prohibit and even consider poligamy as an unlawful act for any reasons. Within such a context Shaykh Mushthafā al-'Adawī wants to give a full explanation about the understanding on poligamy especially that is related to the concept of equality in the poligamy by interpreting qur'anic verses which are understood controversially by using the methode of interpreting the Qur'an with other verses of the Qur'an, sound narration, munāsabah al-ayāt (interralated quranic verses), and the context of the verse of poligamy itself.
\end{abstract}

Key words: Adil; al-Tashīl li Ta'wīl al-Tanzīl; Mushthafā al-Adawī

\begin{abstract}
ABSTRAK
Poligami telah menjadi isu sensitif dan perdebatan sengit antara para ulama, ilmuwan Muslim, dan penafsir Alquran sejak dahulu kala. Ada tiga pendapat dalam menafsirkan ayat-ayat yang dianggap sebagai sumber hukum tentang poligami dan yang ada dalam kitab-kitab tafsir Alquran.
\end{abstract}


Pertama, kelompok penafsir yang mengizinkan poligami dan sangat fleksibel. Kedua, kelompok penafsir yang mengizinkan poligami namun memiliki persyaratan yang sangat ketat. Ketiga, kelompok penafsir yang menolak dan melarang dan bahkan menganggap poligami sebagai tindakan melanggar hukum karena alasan apapun. Dalam konteks seperti itu, Syekh Mushthafā al-Adawī ingin memberikan penjelasan lengkap tentang pemahaman poligami terutama yang berkaitan dengan konsep kesetaraan dalam poligami dengan menafsirkan ayat-ayat qur'an yang dipahami secara kontroversial dengan menggunakan metode untuk menafsirkan Qur'an dengan ayat-ayat Al Qur'an lainnya, narasi yang baik, munāsabah al-ayāt, dan konteks ayat poligami itu sendiri.

Kata kunci: Adil; al-Tashīl li Ta'wīl al-Tanzīl; Mushthafā al-Adawì

\section{A. Pendahuluan}

Poligami merupakan salah satu issue yang sensitif dalam Islam, selain masalah warisan dan kepemimpinan perempuan. Dalam Islam, isuisu ini muncul dari pernyataan al-Qur'an yang menjadi sumber ajarannya. Para pemikir Muslim memiliki tanggapan berbeda mengenai poligami, baik di kalangan pemikir Islam klasik sendiri maupun para pemikir Islam kontemporer. Umumnya, titik temu perdebatan itu dalam masalah interpretasi kata adil yang dimaksud al-Qur'an, bukannya pada masalah poligami itu sendiri.

Dalam memahami ayat tentang poligami terjadi perbedaan sehingga menimbulkan pro dan kontra. Perbedaan tersebut terjadi dalam memahami ayat poligami tersebut. Oleh karena itu perlu ada pemahaman yang lebih mendalam lagi untuk memahami ayat poligami tersebut, dan juga harus melihat kepada aspek sejarah pada masa pelaksanaan poligami baik pada masa Rasulullah dan juga melihat situasi dan kondisi masyarakat, apakah membutuhkan poligami atau tidak, sehingga dapat menjadi solusi atau sebaliknya.

Terlepas dari pro-kontra mengenai issue poligami, persoalan ini senantiasa menarik untuk dikaji. Kajian cukup sensasional terkait isu ini digaungkan oleh pemikir mesir Mushtofa al-Adawi, seorasng ilmuan yang mengubah haluan kariernya menjadi seorang penda' Muslim, melalui kitab tafsirnya berjudul AL-Tashil Li Ta'wil al-Tanzil. 
Tulisan ini mengelaborasi pemikiran al-Adawi terkait dengan pandangan-pandangannya mengenai poligami dalam karyanya tersebut. Kajian ini lebih menekan pada kajian karya atau literer dengan pendekatan analisis deskriptif kritis.

\section{B. Pembahasan}

\section{Riwayat Hidup Mushthafã al-'Adawī}

Terkait riwayat hidup Shaykh Mushthafā al-Adawī ini, memang belum ditemukan cukup referensi yang secara komprehensif membicarakan perjalanan kehidupannya. Hal itu disebabkan bahwa hingga saat ini belum ada biografi atau autobiografi yang secara utuh membahas kehidupan Shaykh Mushthafā al-Adawī. Salah satu sumber yang bisa penulis lacak adalah uraian tentang kehidupan Shaykh Mushthafā al-Adawì dalam sebuah artikel yang di tulis oleh Muhammad Abduh dengan judul “Orang Teknik Mesin yang Jadi Ulama” dan dipublikasikan tahun 2009 (http://ustadzaris.com). Di samping itu, sumber yang bisa ditemukan adalah wawancara Mushthafā al-Adawī sendiri dalam beberapa stasion televisi serta dokumentasi yang menceritakan perjalanan hidupnya yang dipublikasikan dan bisa diakses melalui situs youtube. Maka penjelasan tentang Riwayat hidup Shaykh Mushthafā al-Adawī penulis kutip dari artikel dan sumber-sumber youtube tersebut.

Shaykh Mushthafã al-Adawī adalah salah seorang ulama ahli sunnah yang cukup terkenal di dunia Islam dengan latar belakang pendidikan yang sangat unik. Mushthafā al-Adawī lahir di sebuah kampung bernama Maniah Samanūd, sebuah kampung di provinsi al-Daqahliyah Mesir tanggal 17 September 1954. Dia dilahirkan di lingkungan keluarga yang dikenal sangat relegius sekalipun orang tuanya hanya berprofesi sebagai pedagang. Semenjak kecil orang tuanya telah memasukannya ke sekolah tahfiz al-Qur'an di kampung halamannya. Selain itu, Shaykh Mushthafā al'Adawī memang sosok anak yang juga memiliki perhatian dan kecintaan yang besar terhadap al-Qur'an. Hal itu terbukti bahwa saat masih anakanak beliau sudah berhasil menghafal al Qur'an. Selain menghafal alQur'an Mushthafā al-Adawī juga belajar ilmu lainya seperti tata bahasa Arab, hadis, fiqih dan sebagainya (http://www.youtube.com/watch?v=O80GONw2hE). 
Semenjak sekolah dasar hingga sekeloh menengah atas Mushthafā al-Adawī menempuh pendidikan di kampungnya Samanūd. Mushthafāa al'Adawī kemudian melanjutkan studinya di fakultas teknik tepatnya jurusan teknik mesin di Universitas Manshuriyah Mesir pada tahun 1972. Akan tetapi, selain kuliah di fakultas teknik, Shaykh Mushthafā al-Adawī juga aktif dalam berbagai diskusi kampus terutama tentang pemikiran Islam yang pada saat itu sangat marak di berbagai kampus di Mesir. Pada masa aktif kuliah di fakultas teknik ini, Shaykh Mushthafā al-Adawī pergi ke Makkah untuk melaksanakan umrah. Di sinilah awalnya dia mendalami manhaj salafi dan banyak membaca buku-buku salafi (http://www. youtube.com/watch?v=1D3zsjiHjW0).

Setelah menyelesaikan pendidikannya di jurusan teknik Shaykh Mushthafā al-Adawī bukannya memilih profesi sesuai pendidikan yang ditempuhnya. Shaykh Mushthafā al-Adawī justru pergi meninggalkan kampung halamannya dan melakukan rihlah ilmiah (perjalanan dalam rangka menuntut ilmu) ke berbagai belahan dunia Islam. Keinginannya untuk mencari dan menemukan kebenaran yang hakiki telah mendorongnya untuk menemui sejumlah ulama terkenal untuk kemudian belajar tentang ajaran Islam kepada mereka. Yaman adalah tujuan pertama perjalanan ilmiah Shaykh Mushthafā al-Adawī untuk belajar kepada Shaykh Muqbil bin Hādi al-Wadi'ī seorang ulama Hadis terkenal pada waktu itu. Mushthafā al-Adawī belajar dan mengikuti berbagai pelajaran ilmiah yang disampaikan oleh Shaykh Muqbil selama satu tahun sebelum pulang ke Mesir untuk menikah (http://www.youtube.com/watch?v=4t14 zPthpQM\&noredirect=1).

Setelah menikah Shaykh Mushthafā al-Adawī kembali meninggalkan Mesir untuk kembali ke Yaman dan melanjutkan pelajarannya kepada Shaykh Muqbil bin Hādi al-Wadi'ĩ hingga empat tahun. Pada saat di Yaman inilah Shaykh Mushthafāa al-Adawī menunaikan ibadah haji ke Makkah tepatnya pada tahun 1980 M. Selain itu, Mushthafā al-Adawī juga pernah datang ke Pakistan, Yordania, Suria, Lebanon untuk menemui ulama-ulama terkenal pada masanya (http://www.youtube. com/watch?v=c0OqF_k4SaY).

Setelah melakukan pengembaraan ilmiah selama bertahuntahun, tepatnya tahun pada tahun 1985 M, Shaykh Mushthafā al-Adawī 
kemudian kembali lagi ke Mesir untuk mengajarkan ilmu yang telah dipelajarinya sekaligus membangun rumah tangganya secara normal. Shaykh Mushthafā al-Adawī awalnya membangun sebuah mushalla kecil sebagai tempat mengajarkan ilmu yang telah diperolehnya selama bertahun-tahun menimba ilmu. Di mushalla ini Shaykh Mushthafā al'Adawī mulai mengajarkan kitab shahih Bukhari, Muslim, tafsir al Qur'an dan Fiqh. Secara perlahan namun pasti mulai banyak penuntut ilmu yang ingin belajar ilmu-ilmu agama kepada Shaykh Mushthafā al-Adawī baik yang berasal dari Mesir sendiri ataupun di luar Mesir. Berikuutnya Shaykh Mushtafa al'Adawi membangun sebuah masjid besar dan perpustakaan yang besar dan terbilang cukup lengkap koleksi buku-bukunya. Masjid ini kemudian diberi nama oleh Shaykh Mushthafā al-Adawī sendiri dengan nama masjid Ahl al-Sunnah wa al-Jamāah. Di samping mengajar di masjid yang dibangunnya itu, Shaykh Mushthafā al'Adawī juga menghasuh dan membina kajian rutin dalam berbagai bidang keislaman di bebeberapa tempat di Mesir (http://www.youtube.com/watch?v=tlW3PzcQxz8).

Di samping aktivitas mengajar, Shaykh Mushthafā al-Adawī juga sangat aktif menulis dan tergolong tokoh yang sangat produktif. Beragam karya telah dihasilknanya dalam beberapa bidang kajian Islam, seperti fikih, hadits, musthalah hadits dan tafsir. Khusus di bidang tafsir, karyanya diberi judul al-Tashìl li Ta’wîl al-Tanzlì (التسهيل لتأويل التنزيل) yang bisa diartikan "Cara Mudah Belajar Tafsir al-Qur'an”. Tafsir ini memang belum rampung sebanyak tiga puluh juz, namun sampai saat ini telah dipublikasikan sebanyak 15 jilid yaitu tafsir surat al-Fātihah dan al Baqarah sebanyak 3 jilid, tafsir surat Āli 'Imrān 1 jilid, tafsir surat al-Nisā’ 2 jilid, tafsir surat alNūr, al Hujurat, al Qașāṣ, Yūsuf, al-Kahfi, Juz 28, 29 dan 30 yang masingmasing 1 jilid.

Sementara itu, dalam bidang fiqh Shaykh Mushthafā al-'Adawī telah menulis beberapa kitab, di antaranya kitab al-Jāmi' li Aḥkām al-Nisā' (حامع yang merupakan kitab lengkap tentang hukum-hukum yang berkaitan dengan wanita. Kitab ini terdiri dari lima jilid dengan rincian empat jilid berisi uraian tentang beragam persolan wanita sedangkan jilid kelima berisi Tanya jawab praktis tentang kandungan empat jilid sebelumnya. Selain itu, ada kitab al-Jāmi' al-Āmm fi al-Fiqh wa al-Ahkām yang merupakan kitab lengkap tentang fiqh 
dan hukum Islam. Berikutnya ada kitab Fiqh al-Uḍhiyah (فقه الأضحية) yang merupakan sebuah kitab fiqih yang mengkhususkan pembahasannya tentang ibadah qurbān. Ada kitab al-Manīhah fi Aḥkam al-Hajj wa al-'Umrah yang merupakan kitab fiqih yang secara khusus membahas persoalan haji dan umrah dan sunnah yang șahịh. Terdapat juga kitab al-Hijäb Adillat al-Müjibin wa Shibh al-Mukhālifïn (الحجاب أدلة الموجبين وشبه المخالفين) merupakan kitab yang secara komprehensif membahas tentang hijab terutama tentang tata-tata cara berpakaian menurut Islam. Ada kitab al-Mu'anniq fi Ibāḥat Tahallī alNisā' bi al-Dhahab wa al-Muhalliq wa Ghayri Muhalliq (المؤنق في إباحة تحلي) merupakan kitab yang mengupas persoalan tentang perhiasan bagi perempuan terutama tentang pemakian emas dengan mengemukan banyak riwayat tentang kehidupan isteri-isteri Nabi saw persoalan penggunaan emas ini. Ada kitab Mafātīh al-Fiqh fi al-Dìn yang merupakan kitab tentang fikih secara umum. Ada kitab al-Ghasl wa al-Kafn (مفح فين (الغسل والكفن) yang merupakan kitab berisi uraian tentang pelaksanaan jenazah khususnya masalah memandikan dan mengafani mayat. Ada juga kitab Yawāquit al-Falāt fi Mawāqìt al-Ṣalāt yaitu kitab yang khusus membahas tentang bagaimana menentukan waktu shalat. Selanjutnya kitab Ahkām al-Talāq $f i$ al-Sharíah al-Islämiyah (أحكام الطلاق في الشريعة الإسلامية) yaitu kitab yang menguraikan tentang hukum țalaq dan segala sesuatu yang terkait dengan hak dan kewajiban suami dan isteri selama dalam proses țalaq tersebut. Dan ada kitab Bahthu fi 'Adad al-Raka'àt Qiyām al-Layl (قحث في عدد ركعات yang merupakan kitab yang khusus membahas seputar shalat malam termasuk pendapat-pendapat ulama tentang jumlah raka'atnya.

Dalam bidang hadis karya-karya Mushthafā al-'Adawī diantaranya adalah al-Ṣahīh al-Musnad Min Aḥädìth al-Fitan wa al-Malāhim wa Ashrät al-Säah (الصحيح المسند من أحاديث الفتن والملاحم وأشراط الساعة) yang merupakan kitab kumpulan hadits-hadits shahih mengenai huru-hara akhir zaman. Kemudian kitab al-Ṣahịh al-Musnad Min Adhkār al-Yawm wa al-Lylaht (الصحيح المسند من أذكار اليوم والليلة) yaitu sebuah kitab berisi kumpulan hadits shahih mengenai zikir-zikir harian. Berikutnya ada kitab al-Ṣahīh al-Musnad Min Faḍāil al-Ṣaḥābah (الصحيح المسند من فضيائلة yang merupakan kitab mengenai hadits-hadith shahih tentang 
keistimewaan para shahabat Nabi. Berikutnya ada kitab al-Ṣahịh alMusnad Min al-Ahädìth al-Qudsiyah (الصحيح المسند من الأحاديث القدسية) merupakan buku kumpulan hadits-hadits qudsi yang shahih. Berikutnya ada kitab al-Muntkahab Min Musnad 'Abd ibn Ahmmad (عنتخب من مسند) yang merupakan kitab hadis hasil takhrij terhadap kumpulan hadis karya Abū Muḥammad 'Abd ibn Hạamid Nashr al-Kissī yang ditulis awal abda ke 3 Hijrah. Berikutnya ada kitab Taysir Muștalah al-Hadith fi Su'āl wa Jawāb (تيسير مصطلح الحديث في سؤال وجواب) yang merupakan kitab tentang 'ulūm al-hadìth dalam bentuk tanya jawab. Berikutnya kitab Sharh 'Ilal al-Hadith Ma'a As'ilah wa Ajwibah fi Musțalah al-Hadith (أحرح علل (الحديث مع أسئلة وأجوبة في مصطلح الحديث yang merupakan kitab tentang cacat tidaknya sebuah hadis yang juga diuraikan dalam bentuk tanya jawab. Ada kitab As'ilah wa Ajwibah fi Muștalah al-Hadith (أسئلة وأجوبة في مصطح yaitu kitab yang berisi tanya jawab seputar persoalan 'ulūm alhadīth. Dan ada kitab al-Tarshid (الترشيد) yang merupakan kitab berisi kumpulan hadith-hadith tentang ibadah dan akhlak.

Sementara itu di bidang aqidah dan akhlak ada karyanya seperti kitab Adab al-Takhātub (أدب التخاطب) yaitu kitab yang berisi uraian tentang tata cara dan etika berbicara dengan memperhatikan lawan bicara, situasi dan kondisi serta tempat pembocaraan terjadi. Kemudian da kitab al-Istighfär (الاستغفار) yang berisi uraian tentang bagaimana cara meminta ampun agar dosa diampuni oleh Allah. Selanjutnya ada kitab Shifá' al-Qulūb yaitu sebuah kitab yang menguraikan tentang penyakitpenyakit hati dan cara menyembuhkannya. Kemudian ada kitab Fiqh alAkhlāq (فقه الأخلاق) yaitu kitab yang menguraikan persolan akhlak secara umum. Selanjutnya ada kitab Fiqh al-Ḥasad (فقه الحسد) sebuah kitab yang menjelaskan tentang sifat dengki, bahaya dan cara mengobatinya. Berikutnya ada kitab Bahth fi Qawlihi Ta'āla: "Lā taqrabū al-zinā innahu

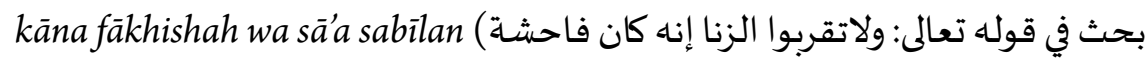
yang merupakan sebuah kitab dimana pembahasannya tentang zina dan segala macam bahaya dan dampak negatifnya baik bagi pelaku maupun masyarakat.

Sementara dalam bidang pendidikan terdapat satu karya berjudul Fiqh Tarbiyat al-Abnā' wa Ṭā'ifat Min Nașā'ih al-Ațibbā'(وقاه تربية الأبناء) yang menjelaskan tentang bagaimana mendidik 
anak serta nasehat-nasehat beberapa dokter terkemuka seputar pendidikan terhadap anak.

\section{Tentang Kitab Tafsir al-Tashîl li Ta'wïl al-Tanzìl}

\section{a. Latar Belakang Penulisanya}

Motivasi atau latar belakang penulisan kitab tafsir al-Tashïl li Ta'wìl al-Tanzil ini disebutkan pengarang dalam muqaddimahnya pada Jilid Juz 'Amma tafsir ini. Sahykh Muṣtafā al-Adawī memulai penjelasannya tentang motivasi penulisan tafsir ini dengan merujuk al-Qurān surat Āli 'Imrān [3]: 79 yang menjelaskan tentang ciri manusia rabbānī (berketuhan) yaitu yang mengajarkan al-Kitab dan terus mempelajarinya. Firman Allah tersebut adalah sebagai berikut.

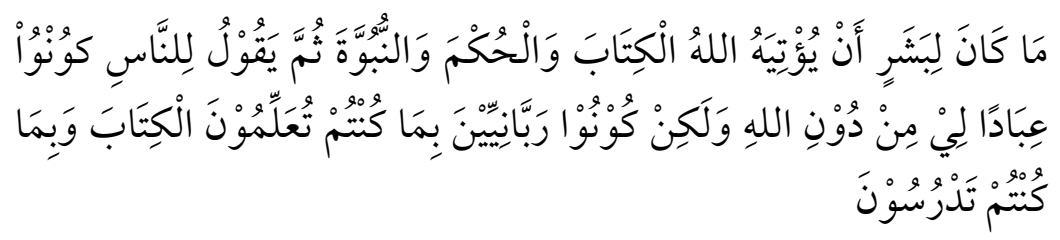

"Tidak wajar bagi seseorang manusia yang Allah berikan kepadanya Al Kitab, hikmah dan kenabian, lalu dia berkata kepada manusia: "Hendaklah kamu menjadi penyembah-penyembahku bukan penyembah Allah." Akan tetapi (dia berkata): "Hendaklah kamu menjadi orang-orang rabbani, karena kamu selalu mengajarkan Al Kitab dan disebabkan kamu tetap mempelajarinya."

Selanjutnya Shaykh Muștafā al-Adawī mengutip sebuah hadis Nabi saw. riwayat al-Bukhārī khayrukum man ta'allama al-qur'ān wa 'allamahu

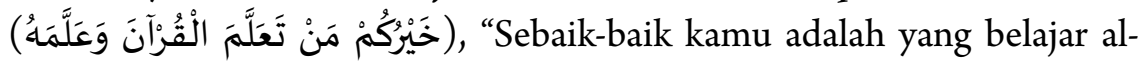
Qửān dan mengajarkannya” (al-Bukhārī, 2002: 1283-1284). Kedua hal inilah yang memotivasi pengarang untuk menghasilakan kitab tafsir yang kemudian dinamakan al-Tashïl li Ta'wìl al-Tanzìl; dorongan untuk menjadi manusia rabbani dan menusia terbaik. Dalam menyusun tafsir ini Shaykh Muștafā al-Adawī memulai dari juz 'A mma dengan alasan bahwa Juz 'Amma dianggap lebih sederhana, karena belum bersentuhan dengan persoalan ibadah, mu'āmalah, atau masalah fiqih lainnya yang penjelasannya juga menuntut seperangkat ilmu lain seperti uṣū fiqh dan takhrij al-hadìth (al'Adawī, 2001: 3-4).

Setelah tafsir Juz 'Amma selesai dan dipublikasikan kemudian mendapat respon yang positif dari masyarakat, Shaykh Muștafā al-Adawī 
melanjutkannya dengan tafsir surat 'Āli 'Imrān dengan pertimbangan yang juga kurang lebih sama dengan tafsir Juz 'Amma sebelumnya. Setelah tafsir surat 'Āli 'Imrān selesai, barulah Shaykh Muștafā al-Adawī melanjutkan tafsir surat al-Fātiḥah dan al-Baqarah yang dianggap sudah memiliki pembahasan yang komplit dengan masalah-masalah fiqhiyahnya seperti nikāh, țalāq, haji, puasa, zakat, jual beli, iman, nazar, termasuk sihir, dengki dan sebagainya (al-Adawī: 6).

\section{b. Sumber Penulisannya}

Dalam Muqaddimahnya, Shaykh Muștafā al-Adawī juga menjelaskan bahwa sumber yang digunakannya dalam tafsirnya ini adalah al-Qur'ān sendiri yaitu penafsiran ayat dengan ayat. Kemudian sunnah Rasūlullāh saw, kemudian athar yang diterima dari para salaf al-șālih, para sahabat dan tābi'în kemudian tābi' al-tābi'īn. Tidak lupa pengarang juga menjelaskan $a s b \bar{a} b$ nuzūl sebuah ayat jika itu ada dengan berdasarkan riwayat yang kuat dan bisa dipertanggungjawabkan validitasnya. Hal itu terlihat dari sumber-sumber riwayat yang digunakan hanya dua sumber yang dipilih yaitu hadis atau riwayat yang terdapat dalam dua kitab shahih Bukhari dan Muslim (al-Adawì: 7).

Dalam memilih sumber sekunder pengarang menyatakan diri sebagai orang yang sangat hati-hati seperti dia berusaha menjauhkan diri sejauh mungkin dari sumber sumber isra'iliyat dan pendapat yang tidak memiliki dasar yang kuat (al-Adawì: 8).

\section{c. Metode penulisannya}

Shaykh Muṣtafā al-Adawī dalam menafsirkan sebuah ayat, selalu memulai penjelasannya dengan penjelasan kosa kata yang dibuat dalam bentuk tabel. Di mana kata-kata yang dianggap kata kunci dijelaskan dalam tabel dengan menyebutkan padanan kata tersebut atau sinonimnya. Kemudian Shaykh Muṣtafā al-Adawī menjelaskan maksud sebuah kata atau kalimat yang terdapat dalam suatu ayat tersebut dengan merujuk kepada beberapa riwayat yang diterima dari Nabi saw.

Metode penyajiannya lebih menarik karena setiap ayat penafsirannya melalui metode dialog dan tanya jawab. Metode ini dipilih Shaykh Muṣtafā al-Adawī berdasarkan apa yang disampaikan dalam pendahuluannya mengikuti metode al-Qur'ān dalam menyampaikan 
pesannya yang juga sering mengajukan pertanyaan untuk kemudian memberikan jawaban (al-Ma'un [107]: 1-7). Bahwa pertanyaan akan terasa lebih menarik pembaca atau pendengar dibandingkan langsung kepada informasi yang hendak disampaikan. Pertanyaan yang diajukan sebagian adalah pertanyaan yang dibuat oleh penulis sendiri, namun ada juga pertanyaan yang berasal dari jama'ah atau muridnya.

Lebih lanjut, dalam muqaddimah tafsir surat Āli 'Imrān Shaykh Muștafā al-Adawī menjelaskan kenapa memilih metode tanya jawab dalam tafsirnya, karena metode bertanya dan mencari jawaban merupakan jalan yang paling baik dalam rangka tafakkur dan tadabbur terhadap ayat-ayat al-Qur'an. Argumentasi yang dikemukan oleh Shaykh Muș̣afāa al-Adawī di

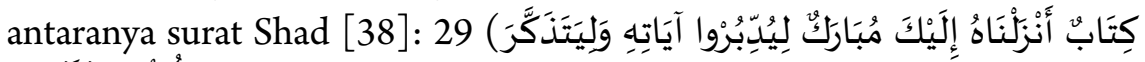

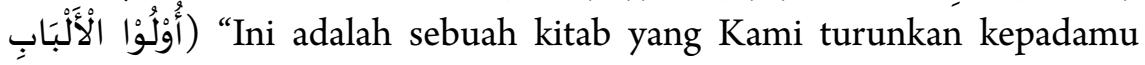
penuh dengan berkah supaya mereka memperhatikan ayat-ayatnya dan supaya mendapat pelajaran orang-orang yang mempunyai pikiran”.

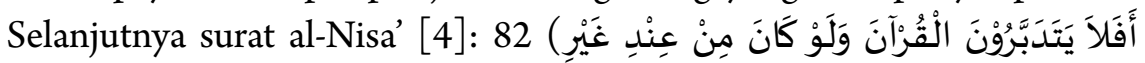
Maka apakah mereka tidak memperhatikan Al-Qur’an? Kalau kiranya Al-Qur'an itu bukan dari sisi Allah, tentulah mereka mendapat pertentangan yang banyak di dalamnya." Dan juga surat

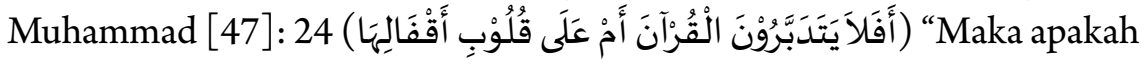
mereka tidak memperhatikan Al-Qur'an ataukah hati mereka terkunci?” (al-Adawì: 6-7).

\section{d. Lawan Tafsirnya}

Terdapat kecenderungan karya tafsir ini dalam beberapa kasus bertentangan dengan tafsir yang dengan corak logis (al-tafsìr bi al-ra'yi) salah satu yang paling kontras adalah dengan tafsīr al-Manär karya Shaykh Muhammad 'Abduh yang kebetulan sama-sama orang Mesir. Seperti dikatakan banyak pengkaji bahwa tafsìr al-Manār adalah tafsir dengan kecenderungan logis (al-tafsïr bi al-ra'yi). Sementara tafsir al-Tashïl li Ta'wīl al-Tanzil memiliki kecenderungan tafsir berdasarkan riwayat (al-tafsir bi al-riwāyah) mengingat Muṣtafāa al-Adawī juga seorang ahli hadith. Dan itu akan terlihat salah satunya dalam kasus penafsiran ayat tentang poligami dan konsep keadilan dalam poligami yang sangat kontras sekali antara kedua ulama ini. Bahkan, kontradisksi tidak hanya terjadi dalam metode yang digunakan, tetapi juga dalam argumentasi yang dikemukan mereka. 


\section{Konsep Adil dalam Poligami Perspektif Muṣtafā al-'Adawī}

Dalam konteks poligami ayat yang selalu menjadi perdebatan para mufassir, fuqahä, cendikiawan hingga para pengamat dan aktivis jender adalah Q.S. al-Nisā' [4]: 3 dan Q.S al-Nisā' [4]: 29. Maka penulis juga ingin menyajikan bagaimana pandangan Muștafā al-Adawī terhadap kedua ayat tersebut, terutama pandangannya terhadap konsep keadilan yang selalu menjadi perdebatan hangat hingga saat ini.

Pertama, Q.S. al-Nisā’ [4]: 3 .

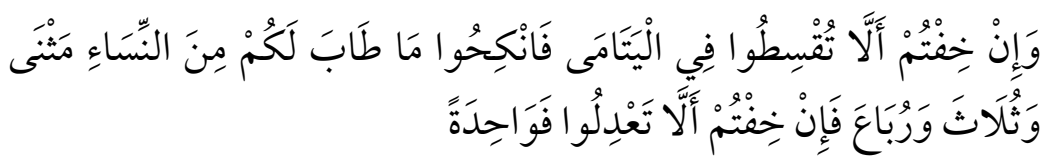

"Jika kamu takut untuk tidak bisa berbuat adil terhadap perempuanperempuan yatim (jika mengawininya), maka nikahilah perempaunperempuan lainnya yang kamu sukai; dua, tiga, empat. Jika kamu takut tidak bisa berbuat adil maka kawinilah satu saja."

Menurut Shaykh Muștafāa al-Adawī bahwa ayat ini adalah bersifat kasus dan khusus. Ayat ini berbicara dalam konteks berpoligami dengan anak yatim. Penjelasan ayat ini harus dilihat munāsabahnya dengan ayat sebelumnya yaitu ayat 2 dan ayat sesudahnya yaitu ayat 4 . Dimana pada ayat 2 surat al-Nisā’ Allah memerintahkan untuk memberikan kepada anak yatim itu hartanya dan tidak sedikitpun mengambilnya.

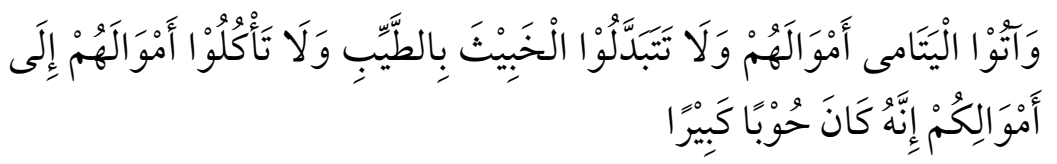

"Dan berikanlah kepada anak-anak yatim (yang sudah balig) harta mereka, jangan kamu menukar yang baik dengan yang buruk dan jangan kamu makan harta mereka bersama hartamu. Sesungguhnya tindakan-tindakan (menukar dan memakan) itu, adalah dosa yang besar."

Adalah sesuatu yang sering terjadi pada masa sebelum Islam bahwa anak yatim sering dinikahi oleh laki-laki yang sudah beristeri untuk sekedar mengambil harta warisan yang dimilikinya untuk kemudian diberikan pula kepada isteri dan anak-anaknya yang lain karena sudah menganggap milik isterinya itu sebagai miliknya. Sehingga menikahi anak yatim dalam konteks ini akan menjadikan seseorang lebih berpeluang berlaku zalim terhadap harta yang sebenarnya bukan haknya (al-Adawī: 41). 
Sementara itu pada ayat sesudahnya yaitu ayat 4 surat al-Nisā, Allah swt. menegaskan kewajiban para suami untuk memberikan mahar kepada para istri yang dinikahinya.

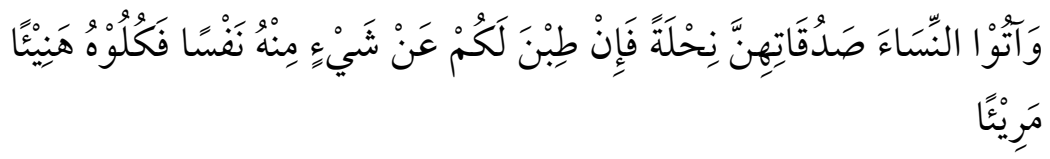

"Berikanlah maskawin (mahar) kepada wanita (yang kamu nikahi) sebagai pemberian dengan penuh kerelaan. Kemudian jika mereka menyerahkan kepada kamu sebagian dari maskawin itu dengan senang hati, maka makanlah (ambillah) pemberian itu (sebagai makanan) yang sedap lagi baik akibatnya."

Pada masa sebelum Islam, dalam kasus mahar juga terjadi pengurangan hak terhadap wanita yanga dinikahi dalam status anak yatim. Di mana para suami seringkali memberikan mahar yang tidak standar seperti layaknya yang diterima oleh wanita yang memiliki orang tua. Hal itu dikarenakan bahwa anak yatim jelas sudah tidak memiliki wali dan juga tidak memiliki hak tawar yang cukup tinggi dalam saat yang bersamaan mereka memang sangat membutuhkan pelindung yang dalam hal ini adalah suami. Maka seringkali para suami memanfaatkan situali dan kelemahan anak yatim ini untuk memberikan mahar yang tidak standar seperti layaknya yang diberikan kepada perempuan lain (al-Adawī: 42).

Menurut Shaykh Muștafā al-Adawi , jika kamu khawatir akan tidak adil dalam menikahi anak yatim dalam praktek seperti itu dan memang dimungkinkan hal itu akan terjadi, maka nikahilah perempuan lain yang baik dalam jumlah dua, tiga atau empat. Dengan demikian, poligami pada asalnya adalah sesuatu yang dibolehkan. Bahkan dalam kesimpulan akhirnya terkait surat al-Nisa' [4]: 3 ini Muṣtafā al-Adawī mengajukan pertanyaan hal yustahabbu táaddudu al-zawjāt? (الم يستحب تعدد)

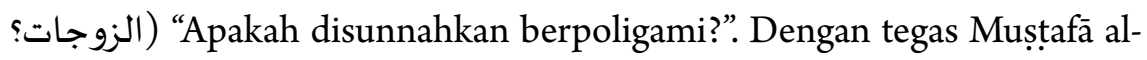
'Adawī menjawab na'am yustahabbu ta'addudu al-zawjāt. نعم يستحب تعدد) "Ya, berpoligami adalah disunnahkan”(al-Adawī, 56). Kemudian Shaykh Muștafā al-Adawī menyebutkan ayat 3 surat al-Nisā’ ini sebagai dalil qaț īnya (al-Maqdisī, 1997: 341).

Dalam memperkuat argumentasinya Shaykh Muștafā al-Adawī menambahkan beberapa hadis Nabi saw. yang menunjukan kesunnahan 
poligami tersebut. Di antara hadis yang dikemukakan adalah hadis dari 'Abdullāh ibn 'Abbās di mana Rasulullah saw. pernah berkata kepada Sa'ìd bin Jubayr, tazawwaj fa inna khayra hādhihi al-ummah aktharuhā nisā'an

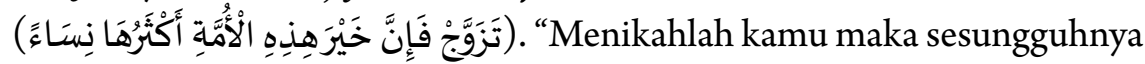
sebaik-baik umat ini yang paling bamyak perempuannya” (al-Bukhārī, 2002:1293).

Shaykh Muṣtafā al-Adawī memberikan penjelasan tentang hadis ini dengan dua pengertian. Pertama, yang dimaksud khayru hädhihi alummah (خير هذه الأمة) adalah Rasūlullāh saw. sendiri. Sementara beliau memiliki isteri lebih dari satu orang. Maka ikutilah aku dengan menikahi perempuan lebih dari satu berdasarkan batasan yang dibolehkan untuk kamu jika kamu juga ingin menjadi manusia terbaik. Kedua, maksud dari ungkapan khayru hādhihi al-ummah (خير هذه الأمة) adalah pintu kebaikan umat ini terletak dalam poligami. Hal itu sesuai dengan al-maqāșid alshar'iyah yang menunjukan betapa banyaknya kebaikan dalam poligami, seperti memelihari kesucian diri baik bagi laki-laki maupun perempuan, juga menjaga kehormatan wanita, memperbanyak keturunan, menjaga anak yatim, melindungi para janda dan sebagainya (al-Adawī, 2006: 92). Bahkan terdapat sebuah penelitian di Malaysia yang menghasilkan sebuah temuan dan kesimpulan betapa poligami sangat berdampak posisitif dalam mengatasi persoalan sosial di Malaysia terutama dalam menekan angka prostitusi (Yasin \& Jani, 2013).

Di samping itu ada hadis Anas bin Malik yang mengatakan bahwa Nabi saw, anna al-nabiy șallallāhu 'alayhi wa sallama kāna yațūfu 'alā nisā'ihi

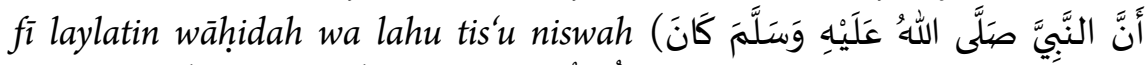

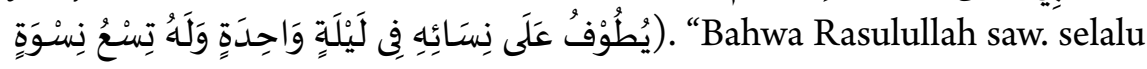
berkeliling di antara isteri-isterinya dalam satu malam dan dia memiliki sembilan isteri” (al-Bukhārī:1293).

Termasuk hadis Nabi saw. yang menyebutkan bahwa perempuan shalih adalah perhiasan terbaik. Al-dunyā matā' wa khayru matā' al-dunyā

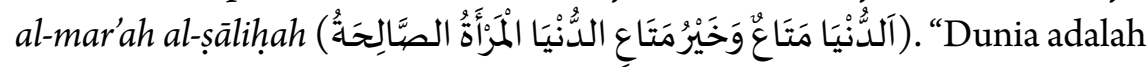
perhiasan dan sebaik-baik perhiasan dunia adalah wanita yang shalihah" (Muslim, 2006: 672).

Begitu juga hadis yang menyatakan bahwa banyak menanggung tanggug jawab adalah bagian dari shadaqah. Wa fi biḍ'i ahadikum șadaqah 


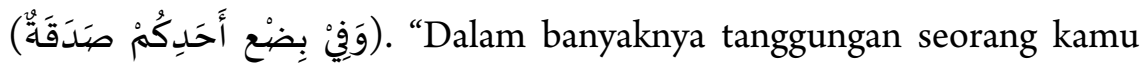
adalah shadaqah” (Ṣahīh Muslim (hadis no. 1006): 448).

Tentu saja sikap Shaykh Mushtafa al-Adawi dalam konteks kebolehan poligami termasuk sikap yang menengah (Nate Olsen, 2009: 93). Karena sikap ulama lain yang ternyata lebih ekstrim dan terbuka dalam menyikapi poligami dengan membolehkan seorang suami mengumpulkan beberapa isterinya di dalam satu rumah walaupun hal tersebut jika isterinya bersedia dan ridha. Bahkan suami juga boleh mengumpulkan isteriisterinya tidur dalam ranjang yang sama dengannya dan suami berada di antara mereka (al-Maqdisī, 1997: 234).

Jika boleh dikomparasikan dengan pendapat Muhammad Abduh dalal tafsirnya al-Manar menegaskan bahwa pada prinsipnya poligami itu tidak sejalan dengan fitrah kehidupan berpasangan yang cenderung monogami (Shaltūt, 1983). Menurut 'Abduh poligami hanya boleh jika situasi masyarakat dalam kondisi darurat dan sangat mendesak seperti dalam suasana peperangan yang menelan banyak korban sehingga banyak sekali janda dan anak yatim yang perlu perlindungan. Itupun baru boleh dengan beberapa persyaratan yang sangat ketat dan bukannya serampangan agar tidak terjadi pedhaliman terhadap hak-hak perempuan ('Abduh). 'Abduh kemudian menunjukkan bukti sosial betapa buruknya dampak poligami bagi sebuah masyarakat dengan membandingkan Negara Mesir yang membolehkan poligami secara besar dengan Negara seperti Turki dan Syiria yang melakukan pembatasan poligami secara ketat (Masnun Tahir, 2008: 221-222). Hasilnya adalah bahwa kerusakan moral di Mesir jauh lebih hebat dibandingkan di Negara seperti Turki dan Syiria ('Abduh, $1367 \mathrm{H}: 350-352$ ). Bahkan tidak sedikit kemudian anak-anak yang menjadi korban baik fisik maupun psikis dari keluarga yang melakukan poligami (Adenike, 2013: 153-156).

Kedua, konsep keadilan dalam surat an-Nisa' [4]: 129.

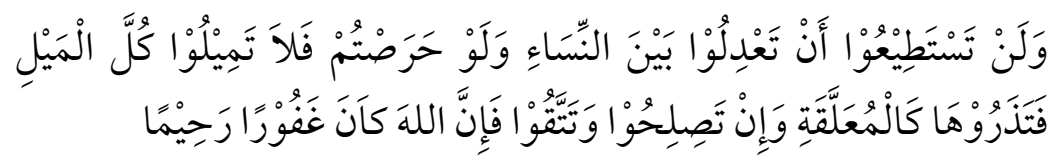

"Dan kamu sekali-kali tidak akan dapat berlaku adil di antara istri- istri (mu), walaupun kamu sangat ingin berbuat demikian, karena itu janganlah kamu terlalu cenderung (kepada yang kamu cintai), sehingga kamu biarkan 
yang lain terkatung-katung. Dan jika kamu mengadakan perbaikan dan memelihara diri (dari kecurangan), maka sesungguhnya Allah Maha Pengampun lagi Maha Penyayang."

Ketika menafsirkan ayat ini Shaykh Muṣtafā al'Adawī memulainya dengan pertanyaan, "mā al-áadl alladhì là yastațīu al-zawju an yaqūma bihi bayna nisā’ihi? (ما العدل الذي لا يستطيع الزوج أن يقوم باء بين نسائه؟), "apakah bentuk keadilan yang tidak bisa ditegakan oleh suami terhadap isteri-isterinya?". Syakh Muṣtafā al'Adawī dengan tegas menjawab “huwa al-'adl fi mahabbat al-qalb wa fi al-jima’ (هو العدل فى محبة القلب والجماع), "yaitu keadilan dalam hal cinta di hati dan sikap serta perlakuan dalam hubungan seksual” (al-Adawī: 323).

Selanjutnya menurut Shaykh Muștafā al'Adawī bahwa yang dimaksud dengan ungkapan wa lan tastațīu an ta'dilū bayna al-nisā'i wa

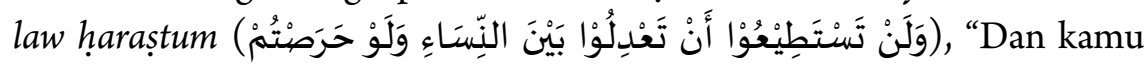
sekali-kali tidak akan dapat berlaku adil" dalam ayat ini adalah rasa cinta, kecondongan hati dan sikap dalam berhubungan seksual (al-Ṭabarī: 284). Adapun perkara-perkara yang zhahir, seperti tempat tinggal, uang belanja dan waktu bermalam, maka wajib bagi seorang laki-laki yang mempunyai isteri lebih dari satu untuk berbuat adil (al-Adawī: 324).

Shaykh Muṣtafā al-Adawī membedakan adil dalam surat alNisā’ [4]: 3 yang disebut dengan kata al-qist (القسط) dengan adil dalam surat al-Nisā' [4]: 29 ini yang disebut dengan istilah al-adl (العدل). Adil yang pertama adalah dalam konteks materi dan nafkah lahiriyah. Maka dalam hal ini seorang suami yang berpoligami memang dituntut untuk berlaku adil dan itu sesuatu yang bisa dan mungkin dilakukan (Shaḥrūr, 1990: 597-598). Sementara keadilan kedua adalah keadilan dalam bentuk perasaan dan termasuk perlakukan seksual yang sudah dipastikan tidak seorang suamipun yang bisa membagi perasaan dan perlakuan seksual yang sama terhadap isteri-isterinya (al-Adawì: 325). Maka keadilan kedua ini bukanlah keadilan yang dituntut yang menjadi syarat boleh atau tidaknya berpoligami. Seorang suami boleh saja lebih mencintai satu isterinya dari yang lain asalkan tidak terlalu mencolok dan berlebihan sehingga mengabaikan isteri yang lain. Itulah yang dimaksud dengan fa lā

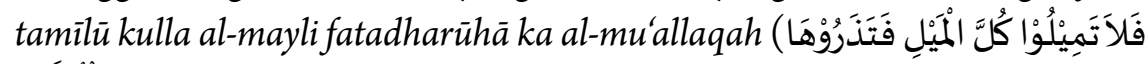
(كَالمُعَلَّقَة 
cintai), sehingga kamu biarkan yang lain terkatung-katung." Kata ka la-

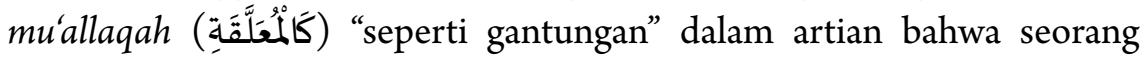
suami yang berpoligami tidak boleh karena sangat cintanya kepada salah satu isterinya kemudian membiarkan isterinya yang lain terkatung-katung, tanpa kepastian hubungan atau dalam bahasa sekarangnya disebut "isteri jablai” alias jarang dibelai (al-Adawī: 324- 325). Oleh karena itu, menurut Shaykh Muṣtafā al-Adawī bahwa ayat ini tidak tepat untuk dijadikan dasar bagi pelarangan poligami (Quraish Shihab, 1995: 201).

Lebih lanjut ditegaskan oleh Shaykh Muṣtafā al-Adawī bahwa keadilan dalam materi adalah sesuatu yang mesti dan harus dipenuhi suami yang memiliki isteri lebih dari satu orang karena itu sangat bisa dilakukan. Alasannya adalah bahwa harta adalah milik dan kepunyaan suami, sehingga dia bisa membaginya secara adil. Berbeda dengan hati, perasaan dan cinta yang tidak bisa dibagai secara adil kepada beberapa orang yang dicintai. Alasannya adalah bahwa hati itu sepenuhnya milik Allah swt. dan manusia tidak bisa dan tidak berwenang membaginya secara adil. Salah dasarnya adalah surat al-Ahzāb [33]: 4.

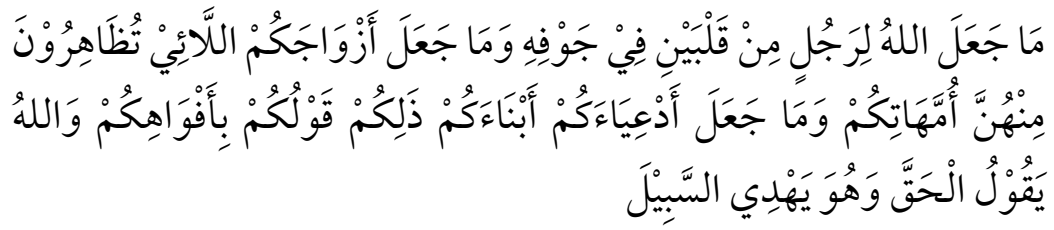

"Allah sekali-kali tidak menjadikan bagi seseorang dua buah hati dalam rongganya; dan Dia tidak menjadikan istri-istrimu yang kamu zhihar itu sebagai ibumu, dan Dia tidak menjadikan anak-anak angkatmu sebagai anak kandungmu (sendiri). Yang demikian itu hanyalah perkataanmu di mulutmu saja. Dan Allah mengatakan yang sebenarnya dan Dia menunjukkan jalan (yang benar).

Dalam konteks ini justru seorang suami wajib tidak berlaku adil karena memang tidak akan bisa betapapun seorang laki-laki mencobanya. Hal ini juga didasarkan kepada riwayat yang diterima dari Muhammad ibn 'Umar dari Abu 'Āṣim dari 'Isā dari ibn Abī Najịh dari Mujāhid bahwa Rasūlullah bersabda, wa lan tastațî̀u an tádilū bayna al-nisā'i wa law

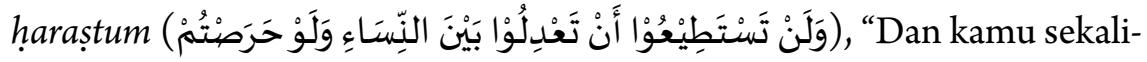
kali tidak akan dapat berlaku adil”. Dia berkata, wājibun an là tastațî́ú al- 
'adl baynahunna (واجب أن لا تستطيعوا العدل بينهن), "wajiblah bahwa kamu tidak bisa berlaku adil terhadap mereka” (al-Ṭabarī: 284).

Konsep keadilan dalam poligami yang dikemukakan oleh Shaykh Muṣtafā al-Adawī ini sangat berbeda jika dibandingkan dengan pendapat yang dikemukakan Muhammad 'Abduh. Terkait ayat 29 surat al-Nisa' ini. 'Abduh misalnya mengatakan bahwa ia merupakan penegasan akan pelarangan poligami. Karena tidak seorangpun yang bisa berlaku adil secara sempurna kepada isteri-isterinya. Sehingga ayat ini sama saja dengan pelarangan atas poligami karena syaratnya tidak akan pernah bisa terpenuhi (Ghasem Esmaili dkk, 2012: 428). Hal ini sama saja dengan menyuruh seseorang tetapi dengan mengajukan persyaratan yang secara pasti tidak akan pernah bisa dia penuhi. Sehingga, tidak ada makna lain dari perintah tersebut kecuali hanya berupa larangan ('Abduh: 449).

Maka ayat ini merupakan pelajaran yang sangat jelas bagi orang yang mau memikirkannya dan bagi orang yang wara' lagi ingin menjaga diri dari aturan-aturan Allah serta mengegakan hukum Allah sekuat tenaga. Ayat ini akan diabaikan oleh para hamba syhawat dan hawa nafsu yang tidak ada maksud untuk mengawini beberapa wanita kecuali hanya untuk maksud kenikmatan hewani yang sebentar dan bersifat temporal serta mengabaikan tujuan hakiki pernikahan yaitu agar masing-masing yang melakukan akad nikah dari suami dan isteri mendapat ketenangan hakiki yang bernama sakinah ('Abduh: 450). 'Abduh kemudian menguatkan pendapatnya dengan mengemukan surat al-Rūm [30]: 21 .

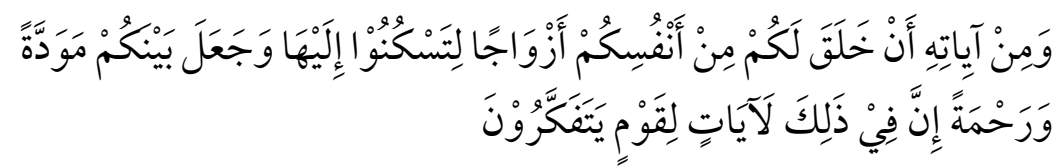

"Dan di antara tanda-tanda kekuasaan-Nya ialah Dia menciptakan untukmu istri-istri dari jenismu sendiri, supaya kamu cenderung dan merasa tenteram kepadanya, dan dijadikan-Nya di antaramu rasa kasih dan sayang. Sesungguhnya pada yang demikian itu benar-benar terdapat tanda-tanda bagi kaum yang berpikir."

Selain menolak ayat 29 surat al-Nisā' tersebut sebagai dasar pelarangan poligami, lebih lanjut Shaykh Muștafā al-Adawī juga memberikan beberapa bantahan terkait pendapat yang melarang atau menolak poligami. Di antaranya; 
Pertama, alasan bahwa poligami akan menjadikan anak keturunan terlantar, tidak terurus dan bahkan tidak tercukupi kebutuhannya apalagi jika anaknya dari beberapa orang isteri mencapai jumlah puluhan. Atas alasan ini Shaykh Muṣtafā al-Adawī mengemukan beberapa ayat yang menjamin rezeki setiap makhluk seperti surat al-Dhāriyāt [51]:22

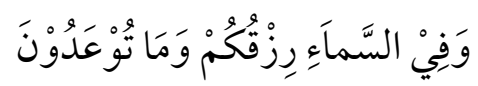

"Dan di langit terdapat (sebab-sebab) rezkimu dan terdapat (pula) apa yang dijanjikan kepadamu."

Begitu juga jaminan Allah dalam surat Thaha [20]: 132.

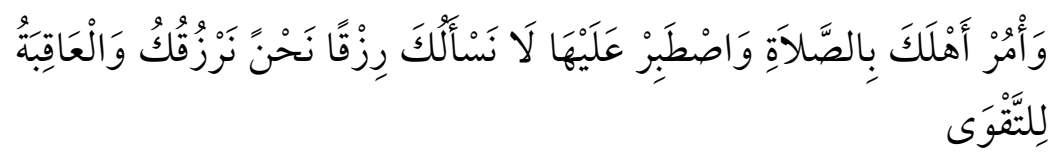

"Dan perintahkanlah kepada keluargamu mendirikan shalat dan bersabarlah kamu dalam mengerjakannya. Kami tidak meminta rezeki kepadamu, Kami lah yang memberi rezeki kepadamu. Dan akibat (yang baik) itu adalah bagi orang yang bertakwa. (al-'Adawì: 59)

Ayat-ayat di atas telah memberikan jaminan pasti kepada setiap makhluk bahwa rezeki mereka sudah dijamin oleh Allah swt. Sehingga, manusia tidak perlu mengkhawatirkannya karena itu berarti menusia telah berlaku musyrik terhadap kuasa Allah swt. Bahkan Shaykh Muștafā al-Adawī menambahkan sebuah hadis yang diriwayatkan Bukhāri dan Muslim.

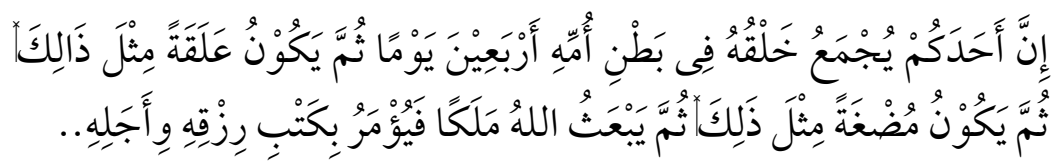

"seseorang kamu dihimpunkan dalam perut ibunya ketika berumur 40 hari, kemudian dia berubah menjadi alaqah 40 hari kemudian, dan berubah menjadi mudghah 40 hari kemudian, dan barulah Allah mengutus malaikat untuk menuliskan rezeki dan ajalnya." (Șahìh al-Bukhārī, (hadis no. 6594), h. 1635 dan Șahīh Muslim (hadis no. 2643), h. 1260)

Kedua, adapun pensyaratan yang diberikan oleh sebagian ulama bahwa seorang suami baru boleh menikah lagi jika isteri pertamanya memiliki cacat fisik yang tidak memungkinkan melayani suaminya secara biologis. Atas dasar ini Shaykh Muștafā al-Adawī memberikan bantahan bahwa prakteknya nabi Muhammad saw. menikahi 'Aisyah dalam keadaan 
perawan dan masih sangat muda. Namun, setelah menikahi 'Aisyah ternyata nabi Muhammad saw. juga menikahi tujuh perempuan sesudahnya (al'Adawì: 59).

Ketiga, ada pendapat yang mengatakan bahwa yang melakukan poligami sebenarnya adalah para hamba syahwat dan budak birahi. Dengan bahasa yang lantang Shaykh Mușțafā al-Adawī mengatakan bahwa itu adalah pendapat para juhalä' (orang-orang bodoh). Shaykh Muṣtafā al'Adawī kemudian mengatakan bahwa nabi Muhammad saw. adalah makhluk paling mulia dan agung, namun memiliki isteri sampai sembilan orang. Begitu juga para sahabat yang mulia yang hampir tidak ada di antara para sahabat yang mulia tersebut yang tidak berpoligami (al'Adawī: 59). Dengan alasan seperti itu, sama saja mereka juga menuduh nabi Muhammad saw. dan para sahabatnya sebagai hamba syahwat dan birahi.

Keempat, alasan yang dikemukakan oleh sebagian ulama bahwa poligamai pada intinya adalah pendzaliman terhadap perempuan. Terhadap pendapat ini Muștafā al-Adawī mengatakan bahwa pendapat itu adalah pendapat kaum atheis dan komunis yang tidak percaya kepada Tuhan. Bagaimana mungkin Tuhan menyuruh manusia dengan hukum-Nya untuk hamba-Nya berlaku dzalim kepada sesama. Secara tidak langsung pendapat seperti ini seakan menuduh Tuhan telah berlaku dzalim kepada makhluknya melalui hukum yang diturunkan-Nya (al-Adawì:59-60). Shaykh Muștafā al-Adawī kemudian memperkuat argumentasinya dengan surat al-An'am [6]: 144.

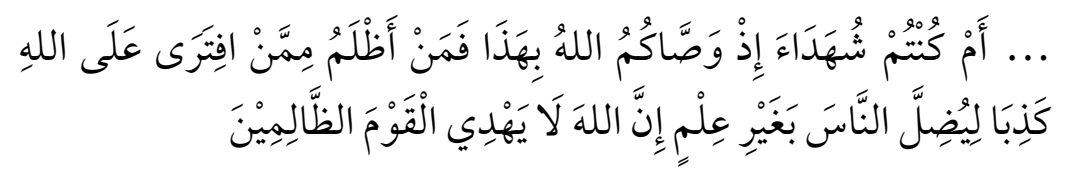

"....Apakah kamu menyaksikan di waktu Allah menetapkan ini bagimu? Maka siapakah yang lebih zalim daripada orang-orang yang membuat-buat dusta terhadap Allah untuk menyesatkan manusia tanpa pengetahuan?" Sesungguhnya Allah tidak memberi petunjuk kepada orang-orang yang zalim."

Menurut hemat penulis sendiri, bahwa poligami memang tidak boleh dilarang karena pelarangan poligami bukan hanya akan mengabadikan polemik teologis yang tidak akan pernah berakhir di kalangan umat Islam, 
namun juga akan melahirkan banyak persolan baik psikologis, moral maupun sosial. Pintu poligami harusnya dibuka, namun dengan catatan bahwa pemerintah harus campur tangan untuk mengeluarkan peraturan atau undang-undang tentang hak-hak dan kewajiban suami dan isteri yang melakukan poligami. Ketentuan-ketentuan ini harus tegas dan bersifat mengikat semua pihak yang terlibat dalam poligami tersebut agar hakhak isteri atau wanita yang menjalankan poligami tidak terabaikan atau bahkan terdzalimi (Abdullah, 2003: 143-144).

\section{Simpulan}

Dari uraian di atas terlihat kecenderungan Shaykh Muștafā al'Adawī dalam kasus poligami sangat salafi. Shaykh Muṣtafā al-Adawī lebih cenderung memahami ayat-ayat ataupun hadis-hadis yang dijadikannya dasar dan argumentasi secara tekstual. Latar belakang keilmuannya yang lebih banyak bersentuhan dengan ulama hadis menjadikan Shaykh Muṣtafā al-Adawī sangat kental dengan warna riwayahnya dalam menafsirkan alQurān. Namun, hal yang berbeda dengan kitab-kitab tafsir sebelumnya dan yang kemudian menjadikannya unik dan memiliki ciri khas tersendiri adalah metode penyajian tafsir dengan pola dialog atau tanya jawab. Sehingga, penjelasan yang dilakukan dalam tafsir ini bukan hanya sekedar menarik, sangat unik tetapi juga merupakan terobosan baru dalam khazanah tafsir di dunia Islam. 


\section{BIBLIOGRAFI}

'Abduh, Muhạmmad, Tafsìr al-Manār. Miṣr: Dār al-Manār, 1367 H.

Abdullah, Raihanah $\mathrm{Hj}$., "Berpoligami: Antara Hak Suami dan Hak Isteri Menurut Undang-Undang Keluarga Islam di Malaysia”, Jurnal Syariah Vol 11, No. 2, 2003.

Al-Adawī, Mușțafā ibn. al-Tashīl li Táwīl al-Tanzīl, al-Manșūrah: Dār alKhulafä', 2001.

Adenike, Adesehinwa Olayinka. "Effects of family type (monogamy or polygamy) onstudents' academic achievement in Nigeria" International Journal of Psychology and Counselling, Vol. 5 (7), (Oktober 2013).

Al-Bukhārī, Abū 'Abdillāh Muhạmmad ibn Ismāîl. Șaḥịh al-Bukhārī. Beirut: Dār Ibn Kathīr, 2002.

Darwazah, Muḥammad 'Izzat. al-Tafsīr al-Ḥadìth, al-Qāhirah: Dār Ihyā’ alKutub al'Arabiyah, $1383 \mathrm{H}$.

Esmaili, Ghasem. Sadrpushan, Najme. Gorji, Yousef. "Comparison of Life Quality for Men in Monogamy and Polygamy Families”. Interntional Journal of Sociological Research, Vol. 3, No.2, (2012).

Khațīb, 'Abd al-Karīm. al-Tafsìr al-Qur'ān li al-Qur'ān, al-Qāhirah: Dār alFikr al-Arabiy, 1967.

Al-Maqdisī, Abū Muḥammad 'Abdullāh ibn Aḥmad ibn Muḥammad Ibn Qudāmah al-Hanbalī, Al-Mughnī. Riyāḍ: Dār 'Alam al-Kutub, 1997.

Al-Marāghī, Aḥmad Mușțafā, Tafsìr al-Marāghī. Mișr: Sharikah Maktabah wa Maṭba'ah Muștafā al-Bābī al-Ḥalabī wa Awlāduhu, 1946.

Muharram, Tamyiz, "Kritik Konsep Poligami dalam Perspektif KHI Metodologi Syahrur, al-Mawarid: Jurnal Hukum Islam, Jurusan Syari'ah Fak. Agama Islam, UII Yogyakarta, edisi XV, 2006. 
Mulia, Siti Musda, Islam Menggugat Poligami. Jakarta: PT. Gramedia Pustaka Utama, 2004.

Muslim, Abū al-Ḥusayn. Șaḥiḥ Muslim, Riyāḍ: Dār al-Ṭaiyibah, 2006.

Olsen, Nate. "Marriage and Divorce in Islamic and Mormon Polygamy: A Legal Comparison”, Intermountain West Journal of Relegius Studies, Volume 1, Number 1 (2009).

Al-Qāsimī, Muḥammad Jamāl al-Dīn. Tafsìr al-Qāsimì al-Musammā Maḥ̂asin al-Ta'wìl. Al-Qāhirah: Dār Ihyaā’ al-Kutub al-ÁArabiyah, 1956.

Shaltūt, Mahmud, al-Islām 'Aqīdah wa Syarīah. al-Qāhirah: Dār alShurūq, 1983.

Shaḥrūr, Muḥammad. al-Kitāb wa al-Qur'ān: Qirā'ah Mu'āṣirah. Dimasq: al-Ahāli li al-Ṭibāáah wa al-Tawzī', 1990.

Shihab, M. Quraish, Membumikan al-Qur'ān. Bandung: Mizan, 1995.

Smearman, Claire A. "Second Wive's Club: Mapping the Impact of Poliygamy in U.S Immigration Law”, Berkelay Journal of International Law, Volume 27, Issue 2, (2009).

Al-Ṭabarī, Abū Ja far Muhammad ibn Jarīr. Jāmit al-Bayān 'an Ta'wīl alQur'ān, Tahqīqì Muhammad Shākir. al-Qāhirah: Maktabah ibn Taymiyah, tt.

Tahir, Masnun, "Hak-Hak Perempuan dalam Hukum Islam Keluarga Syiria dan Tunisia”, al-Mawarid: Jurnal Hukum Islam, Jurusan Syari'ah Fak. Agama Islam, UII Yogyakarta, edisi XVIII, 2008.

Yasin, Raudlotul Firdaus Binti Fatah \& Jani, Mohd. Shah. “The Positive Role of Polygamy in Reducing Women Socio-Related Problems in Malaysia”, American International Journal of Social Science. Vol 2 No. 3 (Mey, 2013).

Zuhayli, Wahbah, Tafsìr al-Munìr fi al-'Aqìdah wa al-Sharìah wa al-Manhaj. Beirut: Dār al-Fikr, 2009. 


\section{Sumber Online.}

Muhammad Abduh, "Orang Teknik Mesin yang Jadi Ulama, http:// ustadzaris.com/orang-teknik-mesin-yang-jadi-ulama. (Diakses, 9 September 2013).

www.youtube.com/watch?v=O-80GONw2hE

http://www.youtube.com/watch?v=1D3zsJiHjW0

http://www.youtube.com/watch?v=4tl4zPthpQM\&noredirect=1

http://www.youtube.com/watch?v=c0OqF_k4SaY

http://www.youtube.com/watch?v=tlW3PzcQxz8 
